\title{
Preparation and Voltammetric Study of a Composite Titanium Phosphate/Nickel Hexacyanoferrate and Its Application in Dipyrone Determination
}

\author{
Loanda Raquel Cumba \\ Faculdade de Engenharia de Ilha Solteira UNESP - Univ Estadual Paulista \\ Departamento de Física e Química, Av. Brasil Centro \\ 56 CEP 15385-000, Ilha Solteira, SP, Brazil \\ E-mail: loandacumba@gmail.com \\ Urquisa de Oliveira Bicalho \\ Faculdade de Engenharia de Ilha Solteira UNESP - Univ Estadual Paulista \\ Departamento de Física e Química, Av. Brasil Centro \\ 56 CEP 15385-000, Ilha Solteira, SP, Brazil \\ E-mail: bicalho@dfq.feis.unesp.br \\ Daniela Rodrigues Silvestrini \\ Faculdade de Engenharia de Ilha Solteira UNESP - Univ Estadual Paulista \\ Departamento de Física e Química, Av. Brasil Centro \\ 56 CEP 15385-000, Ilha Solteira, SP, Brazil \\ E-mail: daniela_silvestrini@yahoo.com.br \\ Devaney Ribeiro do Carmo (Corresponding author) \\ Faculdade de Engenharia de Ilha Solteira UNESP - Univ Estadual Paulista \\ Departamento de Física e Química, Av. Brasil Centro \\ 56 CEP 15385-000, Ilha Solteira, SP, Brazil \\ E-mail: docarmo@dfq.feis.unesp.br
}

Received: December 29, 2011 Accepted: January 29, $2012 \quad$ Published: April 1, 2012

doi:10.5539/ijc.v4n2p66

URL: http://dx.doi.org/10.5539/ijc.v4n2p66

\begin{abstract}
This paper describes the preparation, characterization and electroanalytical application of a composite consisting of titanium phosphate modified with nickel hexacyanoferrate. Titanium phosphate (TiPh) was formed from the reaction of titanium isopropoxide with $\mathrm{H}_{3} \mathrm{PO}_{4}$ and deionized water. Next, the reaction of $\mathrm{TiPh}$ was performed with a metal ion $\left(\mathrm{Ni}^{+2}\right)$ and potassium Hexacyanoferrate, designated as TiPhNIHCF. Spectroscopic techniques such as vibrational spectroscopy, X-ray diffraction (XRD), diffuse reflectance and cyclic voltammetry were used to characterize the TiPh and TiPhNiHCF. The graphite paste electrode containing TiPhNiHCF exhibited a redox couple with average potential $\left(\mathrm{E}^{\theta}\right)$ of $0.61 \mathrm{~V} v s \mathrm{Ag} / \mathrm{AgCl}\left(\mathrm{KNO}_{3} 1.0 \mathrm{~mol} \mathrm{~L}^{-1} ; v=20 \mathrm{mV} \mathrm{s}^{-1}\right)$ attributed to redox process $\mathrm{Fe}^{\mathrm{II}}(\mathrm{CN})_{6} / \mathrm{Fe}^{\mathrm{III}}(\mathrm{CN})_{6}$. The redox couple presents a sensitive response for determining dipyrone. The system showed a detection limit of $3.75 \times 10^{-4} \mathrm{~mol} \mathrm{~L}^{-1}$ and standard deviation of $1.8 \%$ for $n=3$, with an amperometric sensitivity of $34.84 \mathrm{~mA} / \mathrm{mol} \mathrm{L}^{-1}$. The modified electrode was electrochemically stable and showed good reproducibility.
\end{abstract}


Keywords: Cyclic voltammetry, Titanium phosphate, Nickel hexacyanoferrate, Dipyrone

\section{Introduction}

Titanium dioxide $\left(\mathrm{TiO}_{2}\right)$ is a metal oxide, semiconductor of the $n$ (Stroppa et al., 2008) type. It has been used in various industrial applications such as gas sensors (Atashbar et al., 1997; Tang et al., 1995; Chaudhari et al., 2006), waveguides solar cells (O’Regan et al., 1991) and others (Stroppa et al., 2008). The main methods used in the synthesis of $\mathrm{TiO}_{2}$ in the literature are: sol-gel (Yang et al., 2006; Hussain et al., 2010), hydrothermal method (Linsebigler et al., 1995), the Pechini method and combustion reaction (Almeida et al., 2010). The most important chemical properties of this material are those related to polymorphism, amphoteric (Mazloum-Ardakani et al., 2011) and mainly photochemical (Pipi et al., 2010) systems. The $\mathrm{TiO}_{2}$ has three polymorphs: anatase (tetragonal), rutile (tetragonal) and brookite (orthorhombic) (Costa et al., 2006) and in all these phases the $\mathrm{Ti}^{4+}$ cation is hexacoordinated by oxygen anions. The difference between these forms is the way these octahedrons connect to each other (Mambrini et al., 2008). The phase present in the degradation of photoactive organic and inorganic compounds is anatase, the others do not contribute significantly to the process (Mambrini et al., 2008).

Currently, relevant studies involving the photo degradation of organic compounds (Campanella et al., 2009) and adsorption of heavy metals (Debnath et al., 2011; Beck et al., 1992) are highlighted. Moreover, different and specific properties such as high chemical stability makes the titanium oxide an excellent ion exchange (Gonçalves et al., 2010), a photocatalyst that is very successfully used in the degradation of organic pollutants (Choi et al., 2006) and the elimination of pathogenic organisms (Zhou et al., 2007). Different preparation methods of titanium with phosphoric acid forming titanium phosphate have increasingly been studied, usually because the composite is obtained in powerful metallic ions adsorbents and photocatalysts such as titanium oxide, but with the advantage of a greater surface area and chemical stability (Gonçalves et al., 2010; Bruque et al., 1995), which will certainly influence the increase of the catalytic power and the adsorptive properties of metal ions. It is now known that materials with high surface area are also important in the field of electro-electrocatalysis and especially in the preparation of chemically modified electrodes.

Electrodes chemically modified with titanium phosphate have arousing great interest in the area of electrochemistry (Bruque et al., 1995; Pipi et al., 2010) due to its easy preparation and quick renewal of the electrode surface. Many ways of anchoring compounds electrochemically active on the surface have been investigated in order to shorten the distance between the oxidation-reduction sites involved in electronic transfer reactions (Willner et al., 2000; Murray et al., 1984). In the literature, carbon paste electrodes modified with different matrices were used in the determination of dipyrone, such as an anionic exchange resin charged ions with hexacyanoferrate (III) (Marcolino Jr., 2007) and carbon paste modified with cobalt phthalocyanine (Boni et al., 2011).

Recently Do Carmo et al. (2010) described a new synthetic route for the preparation of titanium phosphate, which after modification, the resulting composite was used for the electrocatalytic determination of $\mathrm{N}$-acetylcysteine. The main feature of this synthesis route is the preparation simplicity, in addition to obtaining a potential material with excellent chemical properties.

In this paper we present the preparation and voltammetric study of nickel hexacyanoferrate (NiHCF) obtained by the interaction with the TiPh in two stages. At the first stage, the TiPh adsorbs $\mathrm{Ni}^{2+}$ and at the second stage the composite formed (TiPhNi) reacts with Hexacyanoferrate, forming a new composite (TiPhNiHCF). The idea is to explore the good ionic conduction of TiPh (Wang et al., 2007) in order facilitate the charge transfer between the TiPh and $\mathrm{NiHCF}$, which occurs with the cationic diffusion between the crystal lattice of $\mathrm{TiPh}$ and of $\mathrm{NiHCF}$ in the composite formed. After rigorous voltammetric studies, the composite was tested in the voltammetric determination of dypirone. Dipyrone (acid 1-phenyl-2,3-dimethyl-5-pyrazolones-4-methilaminometanossulfonico) (Pereira et al., 2002), also known as metamizole, which is an analgesic, antithermic and nonsteroidal antipyretic, widely used with proven efficiency in pharmaceutical formulations (Santos et al., 2009; Amaral et al., 2009; Lucchetti et al., 2011). Various methods are employed for their determination, such as amperometry (Boni et al., 2011), flame emission spectrometry (Lyra et al., 2011), spectrophotometry (Suarez et al., 2011), cyclic voltammetry (Teixeira et al., 2009), liquid chromatography mass spectrometry (Ojha et al., 2009), among others, given that the electrochemical methods are simpler and have a good efficiency.

\section{Experimental}

\subsection{Reagents}

All reagents were analytical grade (p.a Merck) and deionized water, and Milli-Q Gradient system from Millipore 
was used. The Dipyrone solutions were prepared immediately before use.

\subsection{Techniques}

\subsubsection{Fourier Transform Infrared Spectra}

Fourier transform infrared spectra were recorded on a Nicolet 5DXB FTIR 300 spectrometer. Approximately $600 \mathrm{mg}$ of $\mathrm{KBr}$ was grounded in a mortar with a pestle, and sufficient solid sample was grounded with $\mathrm{KBr}$ to make a $1 \mathrm{wt} \%$ mixture to produce $\mathrm{KBr}$ pellets. After the sample was loaded, the sample chamber was purged with nitrogen for at least $10 \mathrm{~min}$. prior the data collection. A minimum of 32 scans was collected for each sample at a resolution of $4 \mathrm{~cm}^{-1}$.

\subsubsection{X-ray Diffraction}

The $\mathrm{X}$ ray diffraction patterns (XRD) were obtained using a Siemens D 5000 diffractometer with $\mathrm{CuK} \alpha(\lambda$ $1.5406 \AA$ radiation), submitted to $40 \mathrm{kV}, 30 \mathrm{~mA}, 0.05^{\circ} \mathrm{s}^{-1}$ and exposed to radiation from 5 up to $80^{\circ}(2 \theta)$.

\subsubsection{Electrochemical Measurements}

Cyclic voltammetric measurements were performed using a potentiostat from Microchemistry, MQP1 model. The electrochemical system used was composed of three electrodes: platinum used as an auxiliar electrode, $\mathrm{Ag}$ $/ \mathrm{AgCl}_{(\mathrm{s})}$ as a reference and modified graphite paste as a working electrode. The working electrode consists of a $15 \mathrm{~cm}$ long glass tube, with inner diameter of $0.30 \mathrm{~cm}$ and external diameter of $0.5 \mathrm{~cm}$, and the internal cavity connected by a copper wire to establish the electrical contact.

The cyclic voltammetry technique was employed to study the electrochemical behavior of titanium (IV) phosphate modified with Nickel hexacyanoferrate. The catalytic current was established by the difference between the current measured in the presence of Dypirone and in its absence. The solutions were bubbled with nitrogen for 10 minutes before the measurements.

\subsection{Preparation of Graphite Paste Electrode Modified with TiPhNiHCF}

The graphite paste modified with TiPhNiHCF was prepared from a mixture containing $40 \%$ (w/w) of $40 \mathrm{mg}$ TiPhNiHCF with $60 \mathrm{mg}$ graphite powder (Aldrich) and $30 \mu \mathrm{L}$ of mineral oil.

\subsection{Synthesis of Titanium Phosphate (TiPh)}

$35 \mathrm{~mL}$ of phosphoric acid (PA $85 \%$ ), $20 \mathrm{~mL}$ of titanium isopropoxide (IV) (Ti[OCH$\left.\left.\left(\mathrm{CH}_{3}\right)_{2}\right]_{4}\right)$ and $10 \mathrm{~mL}$ of deionized water were added into a beaker, respectively. The mixture was left at rest and in the dark for one day. Next, the solid phase formed was separated by a sintered plate funnel (vacuum filtration) and dried at a temperature of $343.15 \mathrm{~K}$. The material was stored in a frosted glass bottle described as TiPh. The reaction of titanium isopropoxide with phosphoric acid is represented by the following equation (Eq. 1).

$$
\mathrm{Ti}(\mathrm{OR})_{4(\mathrm{l})}+4 \mathrm{H}_{3} \mathrm{PO}_{4(\mathrm{aq})} \rightleftharpoons \mathrm{Ti}\left(\mathrm{H}_{2} \mathrm{PO}_{4}\right)_{4(\mathrm{~s})}+4 \mathrm{ROH}_{(\mathrm{l})}
$$

Where $\mathrm{R}$ is isopropyl group.

\subsection{Formation of the Binuclear Complex with the TiPh}

The preparation of the binuclear complex was prepared in two steps. Initially, $4.0 \mathrm{~g}$ of macerated TiPh was added to an ethanolic solution $(99 \%)$ of nickel chloride $\left(1.0 \mathrm{~mol} \mathrm{~L}^{-1}\right)$. The mixture was kept under stirring for one hour at room temperature. The solid phase was then separated by vacuum filtration using a sintered plate funnel and washed several times with ethanol $(99 \%)$. The material was dried at a temperature of $343.15 \mathrm{~K}$ and described as TiPhNi. Next, all TiPhNi obtained was added to a solution of potassium ferricyanide $\left(1.0 \mathrm{~mol} \mathrm{~L}^{-1}\right)$. The mixture was kept under stirring for two hours at room temperature. Then, the material was vacuum filtered, washed with deionized water several times and dried at a temperature of $343,15 \mathrm{~K}$. The material was stored in the dark and designated as TiPhNiHCF.

\section{Results and Discussion}

\subsection{X-ray Diffraction Studies}

The X-ray diffractogram of the TiPh is illustrated in Figure 1(a). The four intense peaks found in the diffractogram of the TiPh have the following characteristics $2 \theta: 11.55 ; 20.73 ; 25.60$ and 35.72 . Through a specific software it was determined that these peaks are characteristic of the compound $\mathrm{Ti}_{3}\left(\mathrm{PO}_{4}\right)_{4}$, whose file is the database JCPDS \#52-327.

Figure 1(b) illustrates the X-ray diffractogram of TiPhNiHCF. The intense peaks found in X-ray diffractogram of TiPhNiHCF have the following characteristics $2 \theta: 11.30 ; 17.16 ; 24.56 ; 25.74 ; 28.29 ; 35.11 ; 35.90$ and 39.00 . The results showed that TiPhNiHCF presented some amorphous and crystalline peaks as well as its precursor 
(TiPh). This different crystallinity can be seen in the chemical behavior of the prepared materials. Through the ICSD-28668 formed, we can see that the composite with crystalline peaks TiPhNiHCF presents the following characteristics $2 \theta: 17.16 ; 25.74$ and 35.90 , also observed in nickel hexacyanoferrate and these values are in agreement with those found in the literature (Mostafa et al., 2010; Chang et al., 2008) for different matrices modified with nickel hexacyanoferrate.

\subsection{Studies in the Infrared Spectroscopy}

Figure 2(c) illustrates the spectrum in the infrared region of TiPh. A broad band was observed in the region of $3400 \mathrm{~cm}^{-1}$, assigned to stretching symmetric and asymmetric $-\mathrm{OH}$. There was a mean and narrow band in 1620 $\mathrm{cm}^{-1}$ assigned to H-O-H bond of water and a strong absorption at $1035 \mathrm{~cm}^{-1}$ which was attributed to $v(\mathrm{P}=\mathrm{O})$ stretching. The band observed at $1400 \mathrm{~cm}^{-1}$ was attributed to $\delta(\mathrm{POH})$ stretching (Costa et al., 2006). The bands with values of 518 and $607 \mathrm{~cm}^{-1}$ correspond to links O-Ti-O (Thakkar et al., 2009). The results are in agreement with that found in the literature (Costa et al., 2006; Pipi et al., 2010) for $\mathrm{Ti}_{3}\left(\mathrm{PO}_{4}\right)_{4}$. All the above bands are present in the spectrum of TiPhNiHCF, as illustrated in Figure 2(b). The vibrational spectrum of TiPhNiHCF showed two peaks at $2168 \mathrm{~cm}^{-1}$ and another at $2099 \mathrm{~cm}^{-1}$, not present in the spectrum of TiPh, assigned to $v$ $(\mathrm{C}=\mathrm{N})$ of $\mathrm{Fe}^{\mathrm{III}}-\mathrm{CN}-\mathrm{Ni}^{\mathrm{iI}}$ and of $\mathrm{Fe}^{\mathrm{II}}-\mathrm{CN}-\mathrm{Ni}^{\mathrm{II}}$, respectively (Mostafa et al., 2010; Fang et al., 2011). These values are close to those described in the literature (Fang et al., 2011; Longchamp et al., 2004; Mostafa et al., 2010; Yang et al., 2007).

Figure 2(a) illustrates the vibrational spectrum of potassium ferricyanide (HCF). This spectrum shows a peak in the $3400 \mathrm{~cm}^{-1}$ region, assigned to stretching symmetric and asymmetric $-\mathrm{OH}$ and a medium intensity band at $1620 \mathrm{~cm}^{-1}$ attributed to H-O-H bond of water. The stretching $v(\mathrm{C}=\mathrm{N})$ in TiPhNiHCF is displaced by about 60 $\mathrm{cm}^{-1}$ to low frequency regions relative to $v(\mathrm{C}=\mathrm{N})$ obtained for the potassium ferricyanide.

\subsection{Electrochemical Characterization of TiPhNiHCF}

Figure 3 illustrates the cyclic voltammogram of graphite paste electrode modified with TiPhNiHCF $(40 \% \mathrm{~m} / \mathrm{m})$. A well defined redox pair (peak I) was observed, with average potential $\mathrm{E}^{\theta}=0.55 \mathrm{~V}$ attributed to redox process $\mathrm{Fe}^{\mathrm{II}}(\mathrm{CN})_{6} / \mathrm{Fe}^{\mathrm{III}}(\mathrm{CN})_{6}$ in the presence of nickel. Literature studies of matrices modified with nickel hexacyanoferrate present different average potential values, however the value found in this paper was close to that found for the nickel hexacyanoferrate (NiHCF) formed on the surface of solid electrodes (Chang et al., 2008; Yang et al., 2007; Chen et al., 2007; Do Carmo et al., 2002).

\subsubsection{Studies on the Effect of Cations and Anions}

The process of oxidation and reduction of modified compounds occurs on the surface of TiPhNiHCF, the cation balance in the electrolyte of the electrode surface containing the material (Thakkar et al., 2009; Do Carmo et al., 2002). Figure 4 illustrates the cyclic voltammograms obtained from studies on the influence of supporting electrolytes in graphite electrode modified with TiPhNiHCF. Different supporting electrolytes were used in the study of alkaline metal cations and anions of salts $\left(\mathrm{LiCl}, \mathrm{NaCl}, \mathrm{KCl}, \mathrm{KNO}_{3}, \mathrm{NaNO}_{3}\right.$ and $\left.\mathrm{NaClO}_{4}\right)$. Through this study we observed that the nature of the cations influence the average potential $\left(\mathrm{E}^{\theta}\right)$ and the current intensities. Through the voltammograms a large shift in the average potential to more positive regions is observed. The cyclic voltammetry showed relatively well defined redox pairs, particularly in the presence of supporting electrolytes $\mathrm{KCl}$ and $\mathrm{KNO}_{3}$ (The choice of electrolyte is fundamentally important in the electrochemical behavior of modified graphite paste electrodes).

The displacement of $\mathrm{E}^{\theta}$, is due to the fact that compounds such as Prussian blue and analogues exhibit structures that have a zeolite cavity, in other words, channels that allow the insertion of small molecules and ions that behave as zeolites (Do Carmo et al., 2002). By having smaller hydrated radius, the $\mathrm{K}^{+}$cation is more easily lodged in the pores of the zeolite structure of the formed NiHCF. For the same anion (for example $\mathrm{NO}^{3}$ ) a shift of $\mathrm{E}^{\theta}=40 \mathrm{mV}$ to more positive potentials was observed when $\mathrm{K}^{+}$is exchanged for $\mathrm{Na}^{+}$. This increase of $\mathrm{E}^{\theta}$ is accompanied with the increase of $\Delta \mathrm{Ep}$, which in this case was of $45 \mathrm{mV}$. Greater displacements of $\mathrm{E}^{\theta}$, and $\Delta \mathrm{Ep}$ are observed when $\mathrm{NaCl}$ is replaced by $\mathrm{KCl}$. When the cation is fixed, for example $\mathrm{K}^{+}$and the $\mathrm{NO}_{3}{ }^{-}$anion is moved to $\mathrm{Cl}^{-}$, there is only a small displacement of $\mathrm{E}^{\theta},(11 \mathrm{mV})$ and of $\Delta \mathrm{Ep}(13 \mathrm{mV})$. Thus, the $\mathrm{NO}_{3}^{-}$anion had little influence on the redox process. All the cations tested showed the presence of only one well-defined redox pair. Through this study the $\mathrm{KNO}_{3}$ could be choosen as the best supporting electrolyte because of its good chemical stability and good voltammetric performance. Table 1 shows the electrochemical parameters of TiPhNiHCF after the electrolyte study.

Figure 5 shows the cyclic voltammograms recorded at different concentrations of $\mathrm{KNO}_{3}\left(1.0 \times 10^{-3}\right.$ a $\left.2.0 \mathrm{M}\right)$. The $\mathrm{E}^{\theta}$ ' moves to more positive values with increasing electrolyte concentration, thus indicating the participation 
of $\mathrm{K}^{+}$ion in the redox process and also a change in the activity of these ions (Jayasri et al., 2006). Figure 5 (inserted graph) presents the mean peak potential due to the logarithm of electrolyte concentration of $\mathrm{KNO}_{3}$. Through this study it can be determined for the graphite paste electrode modified with TiPhNiHCF that the slope is $75 \mathrm{mV}$ per decade concentration of potassium ions, respectively, indicating an almost reversible nenrstian process (Do Carmo et al., 2002).

Figure 6 illustrates the cyclic voltammogram at different $\mathrm{pH}$ values (2-8). It was observed that varying the hydrogen ion concentration there is no change in the intensity of anodic and cathodic peak currents. This is the non-occurrence of the interaction between the $\mathrm{H}^{+}$ions with the cyanide groups (protonation), as they are fully complexed with nickel ions.

Figure 7 illustrates the cyclic voltammogram of TiPhNiHCF at different scan rate (10 to $\left.100 \mathrm{mV} \mathrm{s}^{-1}\right)$. It appears that, with increasing scan rate, there is an increase of the anodic and cathodic current intensity of peak I and a small shift of $\mathrm{E}^{\theta}$, to more positive potential regions.

The inserted graph in Figure 7 shows the linear dependence between the current intensity of the anode / cathode peak and the square root of the scan rate for TiPhNiHCF, featuring a diffusion process (Do Carmo et al., 2002).

Table 2 presents the main electrochemical parameters of TiPhNiHCF at different scan rates. The graphite paste electrode modified with TiPhNiHCF presents a sensitive response for the determination of dipyrone. Figure 8 shows the cyclic voltammograms of the graphite paste modified with $\mathrm{TiPh}$ in the absence (curve a) and in the presence of Dipyrone $1.0 \times 10^{-2} \mathrm{~mol} \mathrm{~L}^{-1}$ (curve c) and the voltammograms of the graphite paste modified with TiPhNiHCF in the absence (curve b) and in the presence of Dipyrone $1.0 \times 10^{-2} \mathrm{~mol} \mathrm{~L}^{-1}$ (curve d). This shows a good response from the graphite paste electrode for the determination of Dipyrone. Figure 9 shows the sensitivity of the graphite paste electrode modified with TiPhNiHCF with different additions of aliquots of Dipyrone.

A significant increase in the anodic current peak intensity and also a slight displacement of the average potential of both peaks to more negative values were observed, when the dipyrone concentration was increased. This sensitivity characteristic presented by the graphite paste electrode modified with TiPhNiHCF makes it susceptible to the analysis of millimolar concentration of dipyrone.

The graphite paste electrode clearly showed two irreversible oxidation peaks ( $v s \mathrm{Ag} / \mathrm{AgCl}(\mathrm{s})$, which occur in $0.59 \mathrm{~V}$ and $1.0 \mathrm{~V}$ (Figure 8c) and these values are very close to those described in the literature (Teixeira et al., 2004).

It is well known that the electrochemical oxidation peak of dipyrone (Figure 8c) is related to the methylamino group, N-methanesulphonate (Teixeira et al., 2004) and Teixeira and collaborators (2004) proposed a mechanism that involves the transfer of two electrons and one proton (Equation 2).<smiles></smiles>

These results suggest that the voltammetric response of the modified electrode is based on the oxidation of dipyrone methanesulphonate group with the metallic $\left(\mathrm{Fe}^{\mathrm{III}}\right)$ center of the inner sphere.

The graph inserted in Figure 9 illustrates the calibration curve of the anodic peak current as a function of concentration of dipyrone for TiPhNiHCF. The modified electrode showed a linear response of $3.0 \times 10^{-4}$ to 8.0 $\times 10^{-3} \mathrm{~mol} \mathrm{~L}^{-1}$ with a corresponding equation $\mathrm{Y}(\mu \mathrm{A})=117.61+34.843 \times 10^{3}$ [Dipyrone] with a correlation coefficient of $r=0.997$.

The method has a detection limit of $3.75 \times 10^{-4} \mathrm{~mol} \mathrm{~L}^{-1}$ and standard deviation of $1.8 \%$ for $n=3$ with an amperometric sensitivity of $34.84 \mathrm{~mA} / \mathrm{mol} \mathrm{L}^{-1}$ for dipyrone.

The modified electrode has enabled current intensity ten times greater than the graphite paste electrode without modifier.

\section{Conclusion}

Through the FT-IR, XRD and cyclic voltammetry analysis we can conclude that the titanium oxide modified 
with phosphoric acid (TiPh), followed by a reaction of a metal ion $\left(\mathrm{Ni}^{2+}\right)$, interacted strongly with potassium hexacyanoferrate forming an extremely electroactive composite (TiPhNiHCF). With the material obtained, it was possible to make modified graphite paste electrodes and conduct analytical studies of the sensitivity of dipyrone. The modified electrodes were stable in all studies. The cyclic voltammogram of the modified electrode containing TiPhNiHCF showed only one redox pair with $\mathrm{E}^{\theta}=0.61 \mathrm{~V}$ attributed to the redox process of the $\mathrm{Fe}^{\mathrm{II}}(\mathrm{CN})_{6} / \mathrm{Fe}^{\mathrm{III}}(\mathrm{CN})_{6}$ in the presence of the binuclear complex formed. The graphite paste electrode modified with TiPhNiHCF presented analytical sensitivity to dipyrone. The modified electrode exhibited a linear response of $3.0 \times 10^{-4}$ to $8.0 \times 10^{-3} \mathrm{~mol} \mathrm{~L}^{-1}$ with a corresponding equation $\mathrm{Y}(\mu \mathrm{A})=117.61+34.843 \times 10^{3}$ [Dipyrone] with a correlation coefficient of $\mathrm{r}=0997$. The method showed a detection limit of $3.75 \times 10^{-4} \mathrm{~mol} \mathrm{~L}^{-1}$ with an amperometric sensitivity of $34.84 \mathrm{~mA} / \mathrm{mol} \mathrm{L}^{-1}$ for dipyrone. When compared to other electroanalytical methods, the main advantage of the modified electrode TiPhNiHCF is the easy manufacturing and the fact that it surface can be easily renewed. This feature is important when one wants to effectively implement various measurements in a short period of time. Another advantage is that it needs no prior chemical treatment.

\section{Acknowledgements}

The authors would like to express their gratitude for the financial support by the Fundação de Amparo à Pesquisa do Estado de São Paulo (FAPESP- Proc. 03/12882-6) and Coordenação de Aperfeiçoamento de Pessoal de Nível Superior (CAPES).

\section{References}

Almeida, E. P., Coutinho, J. P., Freitas, N. L., Kiminami, R. H. G. A., Lira, H. L., \& Costa, A. C. F. M. (2010). Nanopowders of $\mathrm{TiO}_{2}$ obtained by combustion reaction: effect of fuels. NSTI-Nanotech, 1, 566-569.

Amaral, A. P. B., Barbosa, M. S. S., Souza, V. C., Ramos, I. L. T., \& Guedes, R. C. A. (2009). Drug/nutrition interaction in the developing brain: Dipyrone enhances spreading depression in rats. Exp. Neurol., 219, 492-498. http://dx.doi.org/10.1016/j.expneurol.2009.06.017

Atashbar, M. Z., \& Wlodarski, W. (1997). Design, Simulation and Fabrication of Doped $\mathrm{TiO}_{2}$-Coated Surface Acoustic Wave Oxygen Sensor. J. Intellig. Mater. Syst. And Struct., 8, 953-959. http://dx.doi.org/10.1177/1045389X9700801104

Beck, J. S., Vartulli, J. C., Roth, W. J., Leonowicz, M. E., Kresge, C. T., Schmitt, K. D., Chu, C. T. W., Olson, D. H., Sheppard, E. W., Mccullen, S. B., Higgins, J. B., \& Schelenker, J. L. (1992). A new family of Mesoporous molecular sieves prepared with liquid crystal templates. J. Am. Chem. Soc., 114, 10834-10843. http://dx.doi.org/10.1021/ja00053a020

Boni, A. C., Wong, A., Dutra, R. A. F., \& Sotomayor, M. D. P. T. (2011). Cobalt phthalocyanine as a biomimetic catalyst in the amperometric quantification of dipyrone using FIA. Talanta, 85, 2067-2073. http://dx.doi.org/10.1016/j.talanta.2011.07.038

Bruque, S., Aranda, M. A. G., Losilla, E. R., Pastor, P. O., \& Torres, P. M. (1995). Synthesis Optimization and crystal structures of layered metal (IV) hydrogen phosphates, $\alpha-\mathrm{M}\left(\mathrm{HPO}_{4}\right)_{2} \cdot \mathrm{H}_{2} \mathrm{O}(\mathrm{M}=\mathrm{Ti}, \mathrm{Sn}, \mathrm{Pb})$. Inorg. Chem., 34, 893-899. http://dx.doi.org/10.1021/ic00108a021

Campanella, L., \& Constanza, C. (2009). Photosensor of environmental persistence for chemical risk assessment. Ecotoxicol and Environ. Saf., 72, 261-272. http://dx.doi.org/10.1016/j.ecoenv.2005.06.013

Carpani, I., Giorgetti, M., Berrettoni, M., Buldini, P. L., Gazzano, M., \& Tonelli, D. (2006). A new approach for the synthesis of $\mathrm{K}^{+}$- free nickel hexacyanoferrate. J. Solid State Chem., 179, 3981-3988. http://dx.doi.org/10.1016/j.jssc.2006.09.004

Chang, C. Y., Chau, L. K., Hu, W. P., Wang, C. Y., \& Liao, J. H. (2008). Nickel hexacyanoferrate multilayers on functionalized mesoporous silica supports for selective sorption and sensing of cesium. Microporous Mesoporous Mater., 109, 505-512. http://dx.doi.org/10.1016/j.micromeso.2007.05.057

Chaudhari, G. N., Bambole, D. R., Bodade, A. B., \& Padole, P. R. (2006). Characterization of nanosized $\mathrm{TiO}_{2}$ based $\mathrm{H}_{2} \mathrm{~S}$ gas sensor. J. Mater. Sci., 41, 4860-4864. http://dx.doi.org/10.1007/s10853-006-0042-7

Chen, W., \& Xia, X. H. (2007). Highly Stable Nickel Hexacyanoferrate Nanotubes for Electrically Switched Ion Exchange. Adv. Funct. Mater., 17, 2943-2948. http://dx.doi.org/10.1002/adfm.200700015

Choi, H., Stathatos, E., \& Dionysiou, D. D. (2006). Sol-gel preparation of mesoporous photocatalytic $\mathrm{TiO}_{2}$ films and $\mathrm{TiO}_{2} / \mathrm{Al}_{2} \mathrm{O}_{3}$ composite membranes for environmental applications. Appl. Catal., B, 63, 60-67. http://dx.doi.org/10.1016/j.apcatb.2005.09.012 
Costa, A. C. F. M., Vilar, M. A., Lira, H. L., Kiminami, R. H. G. A., \& Gama, L. (2006). Síntese e $\begin{array}{llllll}\text { caracterização de nanopartículas de } \quad \mathrm{TiO}_{2} \text {. Cerâmica, } & 52, & 255-259 .\end{array}$ http://dx.doi.org/10.1590/S0366-69132006000400007

Debnath, S., Nandi, D., \& Ghosh, U. C. (2011). Adsorption-Desorption Behavior of Cadmium (II) and Copper(II) on the Surface of Nanoparticle Agglomerates of Hydrous Titanium (IV) Oxide. J. Chem. Eng. Data, 56, 3021-3028. http://dx.doi.org/10.1021/je200222y

Do Carmo, D. R., Silva, R. M., \& Stradiotto, N. R. (2002). Electrochemical study of $\mathrm{Fe}\left[\mathrm{Fe}(\mathrm{CN})_{5} \mathrm{NO}\right]$ in graphite paste electrode. Eclética Quim., 27, 197-210.

Fang, B., Feng, Y., Wang, G., Zhang, C., Gu, A., \& Liu, M. (2011). A uric acid sensor based on electrodeposition of nickel hexacyanoferrate nanoparticles on an electrode modified with multi-walled graphite nanotubos. Microchim. Acta, 173, 27-32. http://dx.doi.org/10.1007/s00604-010-0509-8

Gonçalves, A. (2010). Obtenção e caracterização de revestimentos compostos de multicamadas $\mathrm{TiO}_{2} / \mathrm{TiN}$. Dissertação (Mestrado). Instituto de Pesquisas Energéticas e Nucleares. São Paulo - SP.

Hussain, M., Ceccarelli, R., Marchisio, D. L., Fino, D., Russo, N., \& Geobaldo, F. (2010). Synthesis, characterization, and photocatalytic application of novel $\mathrm{TiO}_{2}$ nanoparticles. Chem. Eng. J., 157, 45-51. http://dx.doi.org/10.1016/j.cej.2009.10.043

Jayasri, D., \& Narayanan, S. S. (2006). Electrocatalytic oxidation and amperometric determination of BHA at graphite-wax composite electrode with silver hexacyanoferrate as electrocatalyst. Sens. Actuators, B, 119, 135-142. http://dx.doi.org/10.1016/j.snb.2005.11.064

Linsebigler, A. L., Lu, G., \& Yates, J. T. (1995). Photocatalysis on $\mathrm{TiO}_{2}$ Surfaces: Principles, Mechanisms and Selected Results. Chem. Rev., 95, 735-758. http://dx.doi.org/10.1021/cr00035a013

Longchamp, S., \& Goubard, F. (2004). AB 5 -type intermetallic compound as a substrate for nickel hexacyanoferrate modified electrodes. Sens. Actuators, B, 99, $516-524$. http://dx.doi.org/10.1016/j.snb.2003.12.071

Lucchetti, G., Granero, A. L., Almeida, L. G. C., \& Battistella, V. M. (2010). Pancitopenia associada ao uso de dipirona. Relato de caso. Rev. Bras. Clin. Med., 8, 72-76.

Lyra, W. S., Sanches, F. A. C., Cunha, F. A. S., Diniz, P. H. G. D., Lemos, S. G., Silva, E. C., \& Araujo, M. C. U. (2011). Indirect determination of sodium diclofenac, sodium dipyrone and calcium gluconate in injection drugs using digital image-based (webcam) flame emission spectrometric method. Anal. Methods, 3, $1975-1980$. http://dx.doi.org/10.1039/c1ay05197k

Mambrini, G. P. (2008). Síntese de nanocristais coloidais de $\mathrm{TiO}_{2}$ via método solvotermal. Tese (Doutorado), Universidade Federal de São Carlos. São Carlos - SP.

Marcolino Jr., L. H. (2007). Eletrodos voltamétricos e amperométricos para a determinação de espécies de interesse farmacêutico. Tese (Doutorado), Universidade Federal de São Carlos. São Carlos - SP.

Mazloum-Ardakani, M., Beitollahi, H., Taleat, Z., \& Salavati-Niasari, M. (2011). Fabrication and characterization of molybdenum (VI) complex- $\mathrm{TiO}_{2}$ nanoparticles modified electrode for the electrocatalytic determination of L-cysteine. J. Serb. Chem. Soc., 76, 575-589. http://dx.doi.org/10.2298/JSC100504042M

Mostafa, M., El-Absy, M. A., Amin, M., El-Amir, M. A., \& Farag, A. B. (2010). Partial purification of neutron-activation 99Mo from cross-contaminant radionuclides onto potassium nickel hexacyanoferrate (II) column. J. Radioanal. Nucl. Chem., 285, 579-588. http://dx.doi.org/10.1007/s10967-010-0584-7

Murray, R. W. (1984). Chemically modifieds electrodes. Bard, A. J., (ed). Electroanalytical Chemistry, New York, Marcel Dekker.

O’Regan, B., \& Grätzel, M. (1991). A low-cost, high-efficiency solar cell based on dye-sensitized colloidal TiO ${ }_{2}$ films. Nature, 335, 737-740. http://dx.doi.org/10.1038/353737a0

Ojha, A., Rathod, R., \& Padh, H. (2009). Quantification of 4-methylaminoantipyrine, the active metabolite of dipyrone, in human plasma. Bioanalysis, 1, 293-298. http://dx.doi.org/10.4155/bio.09.26

Pereira, A. V., Penckowski, L., Vosgerau, M., \& Sassá, M. F. (2002). Determinação espectrofotométrica de dipirona em produtos farmacêuticos por injeção em fluxo pela geração de íons triiodeto. Quim. Nova, 25, 553-557. http://dx.doi.org/10.1590/S0100-40422002000400008 
Pipi, A. R. F., \& Do Carmo, D. R. (2010). Voltammetric studies of titanium (IV) phosphate modified with copper hexacyanoferrate and electroanalytical determination of $\mathrm{N}$-acetylcysteine. J. Appl. Electrochem., 41, 787-793. http://dx.doi.org/10.1007/s10800-011-0296-x

Pipi, A. R. F. (2010) Propriedades Analíticas de materiais a base de sílica e óxido de titânio modificados. Dissertação (mestrado), Faculdade de Engenharia de Ilha Solteira-UNESP Ilha Solteira - SP.

Santos, W. T. P., Gimenes, D. T., Almeida, E. G. N., Eiras, S. P., Albuquerque, Y. D. T., \& Richter, E. M. (2009). Simple flow injection amperometric system for simultaneous determination of dipyrone and paracetamol in pharmaceutical formulations. J. Braz. Chem. Soc., 20, 1249-1255. http://dx.doi.org/10.1590/S0103-50532009000700008

Stroppa, D. G., Giraldi, T. R., \& Leite, E. R. (2008). Nanostructured $\mathrm{TiO}_{2}$ thin films by polymeric precursor method. Quim. Nova, 31, 1706-1709. http://dx.doi.org/10.1590/S0100-40422008000700020

Suarez, W. T., Pessoa-Neto, O. D., Vicentini, F. C., Janegitz, B. C., Faria, R. C., \& Fatibello-Filho, O. (2011). Flow Injection Spectrophotometric Determination of Dipyrone in Pharmaceutical Formulations Using Fe (III) as Reagent. Anal. Lett., 44, 340-348. http://dx.doi.org/10.1080/00032719.2010.500777

Tang, H., Prasad, K., Sanjinés, R., \& Lévy, F. (1995). TiO 2 anatase thin films as gas sensors. Sens. Actuat. B, 26, 71-75. http://dx.doi.org/10.1016/0925-4005(94)01559-Z

Teixeira, M. F. S., Marcolino-Junior, L. H., Fatibello-Filho, O., Moraes, F. C., \& Nunes, R. S. (2009). Determination of Analgesics (Dipyrone and Acetaminophen) in Pharmaceutical Preparations by Cyclic Voltammetry at a Copper(II) Hexacyanoferrate(III) Modified Graphite Paste Electrode. Curr. Anal. Chem., 5, 303-310. http://dx.doi.org/10.2174/157341109789077759

Teixeira, M. F. S., Marcolino-Júnior, L. H., Fatibello-Filho, O., Dockal, E. R., \& Cavalheiro, E. T. G. (2004). Voltammetric determination of dipyrone using a N,N'-ethylenebis (salicylideneaminato) oxovanadium (IV) modified graphite-paste electrode. J. Braz. Chem. Soc., 15, 803-808. http://dx.doi.org/10.1590/S0103-50532004000600003

Thakkar, R., \& Chudasama, U. (2009). Synthesis, characterization and proton transport properties of a mixed material - Zirconium titanium phosphate, a tetravalent bimetallic acid salt. Electrochim. Acta, 54, 2720-2726. http://dx.doi.org/10.1016/j.electacta.2008.11.030

Wang, Q., Zhang, L., Qiu, L., Sun, J., \& Shen, J. (2007). Fabrication and Electrochemical Investigation of Layer-by-Layer Deposited Titanium Phosphate/Prussian Blue Composite Films. Langmuir, 23, 6084-6090. http://dx.doi.org/10.1021/la700239r

Willner, I., \& Katz, E. (2000). Integration of Layered Redox Proteins and Conductive Supports for Bioelectronic Applications. Angew. Chem. Int. Ed., 39, 1180-1218 http://dx.doi.org/10.1002/(SICI)1521-3773(20000403)39:7\%3C1180::AID-ANIE1180\%3E3.0.CO;2-E

Yang, H., Zang, K., Shi, R., Li, X., Dong, X., \& Yu, Y. (2006). Sol-gel synthesis of $\mathrm{TiO}_{2}$ nanoparticles and photocatalytic degradation of methyl orange in aqueous $\mathrm{TiO}_{2}$ suspensions. J. Allyos Compd., 413, 302-306. http://dx.doi.org/10.1016/j.jallcom.2005.06.061

Yang, M., Jiang, J., Lu, Y., He, Y., Shen, G., \& Yu, R. (2007). Functional histidine/nickel hexacyanoferrate $\begin{array}{lllll}\text { nanotube assembly for biosensor applications. Biomater., } & 28, & 3408-3417 .\end{array}$ http://dx.doi.org/10.1016/j.biomaterials.2007.04.020

Zhou, W., Zhong, X., Wu, X., Yuan, L., Shu, Q., Li, W., \& Xia, Y. (2007). Low temperature deposition of nanocystalline $\mathrm{TiO}_{2}$ films: enhancement of nanocrystal formation by energetic particle bombardment. J. Phys. D: Appl. Phys., 40, 219-226. http://dx.doi.org/10.1088/0022-3727/40/1/018 
Table 1. Main voltammetric parameters of TiPhCoHCF in the presence of different supporting electrolytes

\begin{tabular}{|c|c|c|c|c|c|}
\hline Electrolyte & $\left(I_{\mathrm{pc}} / I_{\mathrm{pa}}\right)_{1}$ & & $*\left(E^{\theta,}\right)_{1}(\mathbf{V})$ & $*(\Delta E p)_{1}(\mathbf{V})$ & $\begin{array}{c}\text { Diameter of the } \\
\text { hydrated cation }(\mathrm{nm})\end{array}$ \\
\hline $\mathrm{KNO}_{3}$ & 1.03 & & 0.550 & 0.14 & 0.240 \\
\hline $\mathrm{NaNO}_{3}$ & 0.828 & & 0.511 & 0.185 & 0.360 \\
\hline $\mathrm{KCl}$ & 1.09 & & 0.558 & 0.153 & 0.240 \\
\hline $\mathrm{NaCl}$ & 1.24 & & 0.781 & 0.177 & 0.360 \\
\hline LiCl & 0.897 & & 0.553 & 0.197 & 0.470 \\
\hline $\mathrm{NaClO}_{4}$ & 1.29 & & 0.748 & 0.165 & 0.360 \\
\hline \multicolumn{6}{|c|}{$* E^{\theta}(\mathrm{V})=\left(E_{\mathrm{pa}}+E_{\mathrm{pc}}\right) / 2$ e $\Delta E \mathrm{p}(\mathrm{V})=\left|E_{\mathrm{pa}}-E_{\mathrm{pc}}\right|$} \\
\hline$v\left(m V s^{-1}\right)$ & & {$[\mathbf{I p a} / \mathbf{I p c}]$} & & $\left(E^{\theta^{\prime}}\right)_{1}(\mathbf{V})^{*}$ & $\begin{array}{c}\Delta E \mathrm{p}(\mathrm{V})^{*} \\
{[E \mathrm{pa}-E \mathrm{pc}]}\end{array}$ \\
\hline 10 & & 0.855 & & 0.555 & 0.154 \\
\hline 20 & & 0.878 & & 0.559 & 0.157 \\
\hline 30 & & 0.922 & & 0.562 & 0.164 \\
\hline 40 & & 0.928 & & 0.563 & 0.167 \\
\hline 50 & & 0.936 & & 0.564 & 0.174 \\
\hline 60 & & 0.940 & & 0.565 & 0.179 \\
\hline 70 & & 0.984 & & 0.567 & 0.180 \\
\hline 80 & & 0.995 & & 0.569 & 0.182 \\
\hline 90 & & 0.998 & & 0.567 & 0.190 \\
\hline 100 & & 1.00 & & 0.567 & 0.194 \\
\hline
\end{tabular}

$* E^{\theta},(\mathrm{V})=\left(E_{\mathrm{pa}}+E_{\mathrm{pc}}\right) / 2$ e $\Delta E \mathrm{p}(\mathrm{V})=\left|E_{\mathrm{pa}}-E_{\mathrm{pc}}\right|$ 

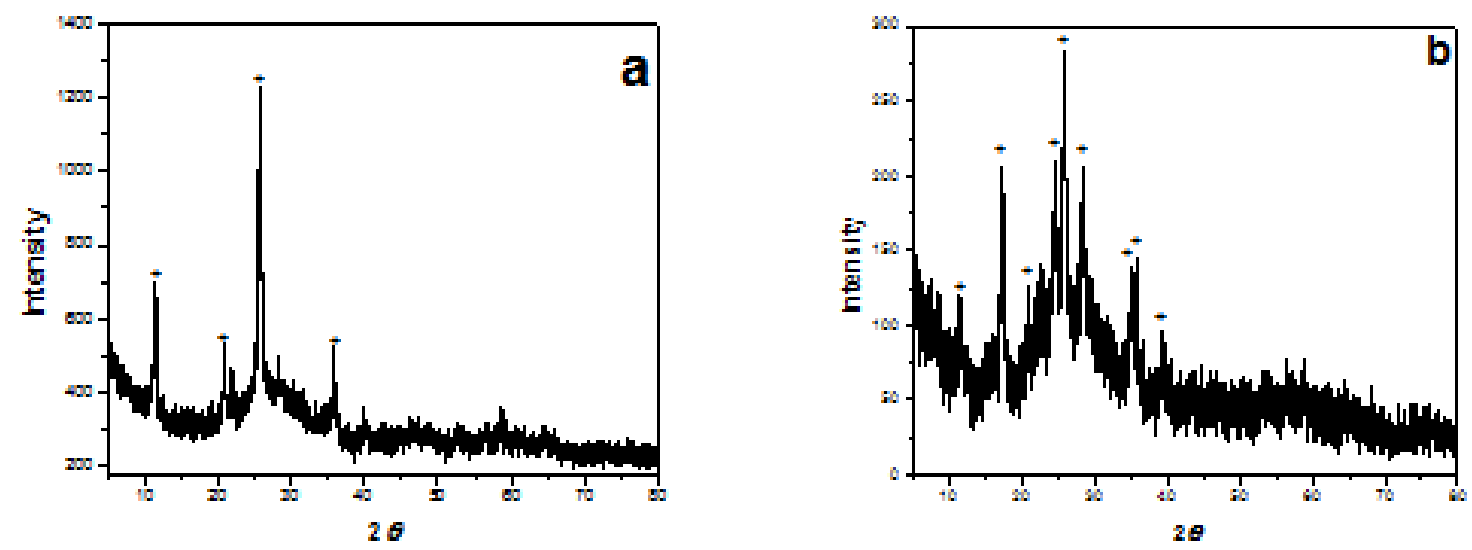

Figure 1. X-ray diffractogram of: (a)TiPh and (b) TiPhNiHCF

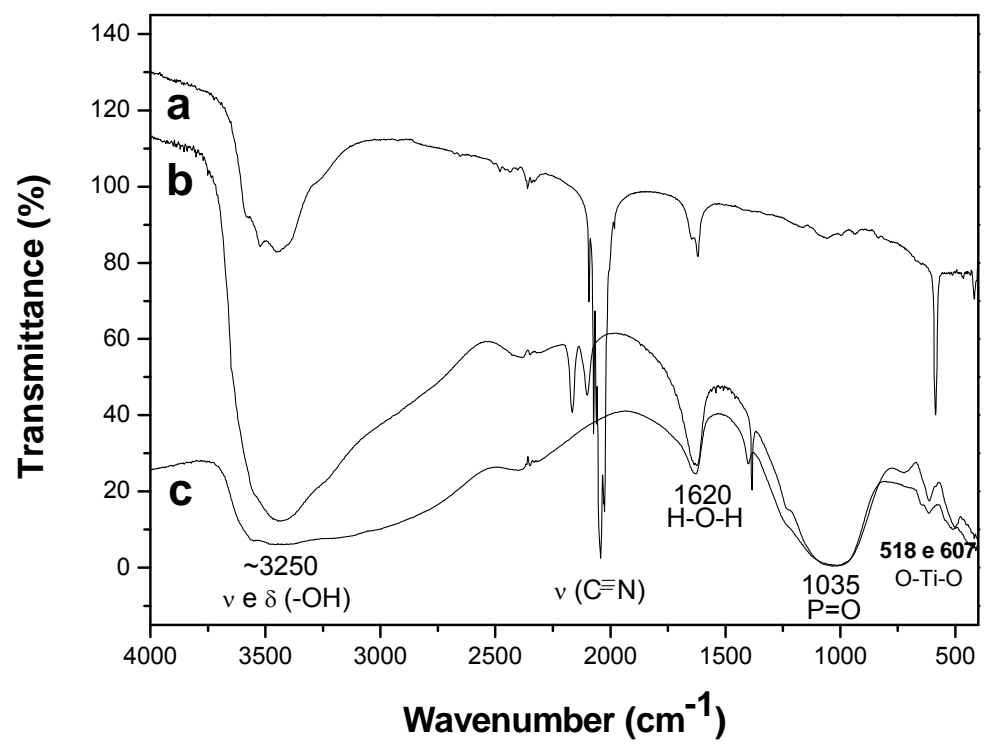

Figure 2. Infrared spectrum of: (a) HCF, (b) TiPhNiHCF and (c) TIPh

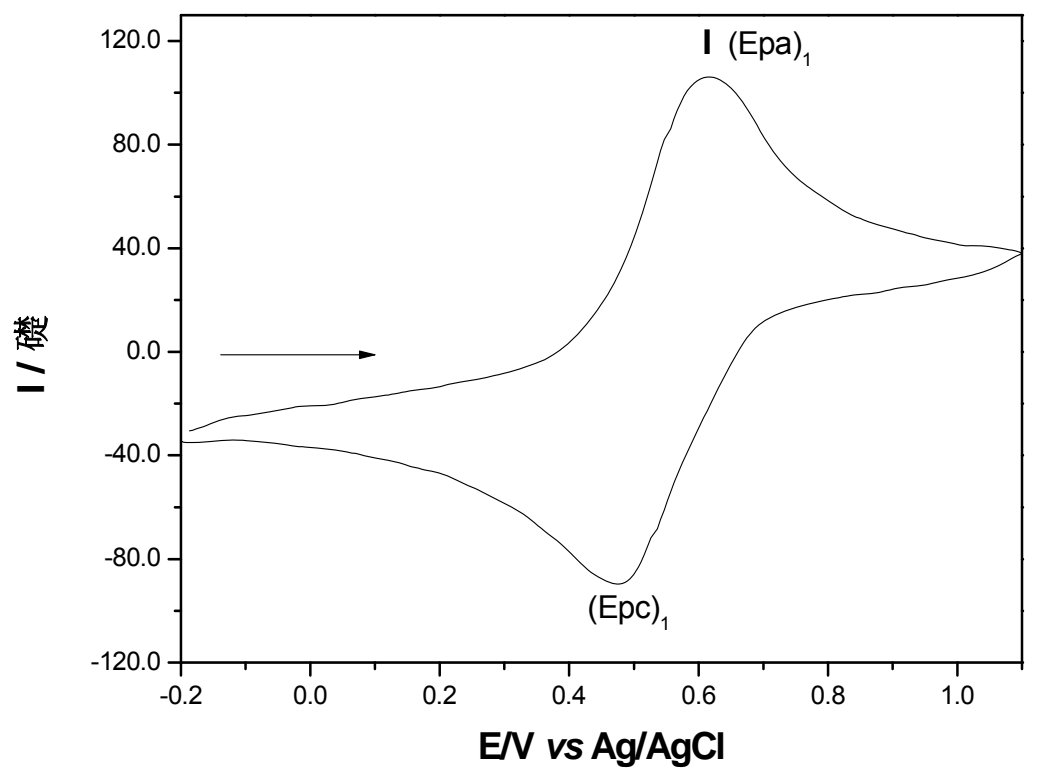

Figure 3. Cyclic voltammogram of graphite paste modified with TiPhNiHCF $\left(v=20 \mathrm{mV} \mathrm{s}^{-1}, \mathrm{KCl} 1.0 \mathrm{molL}^{-1}\right)$ 

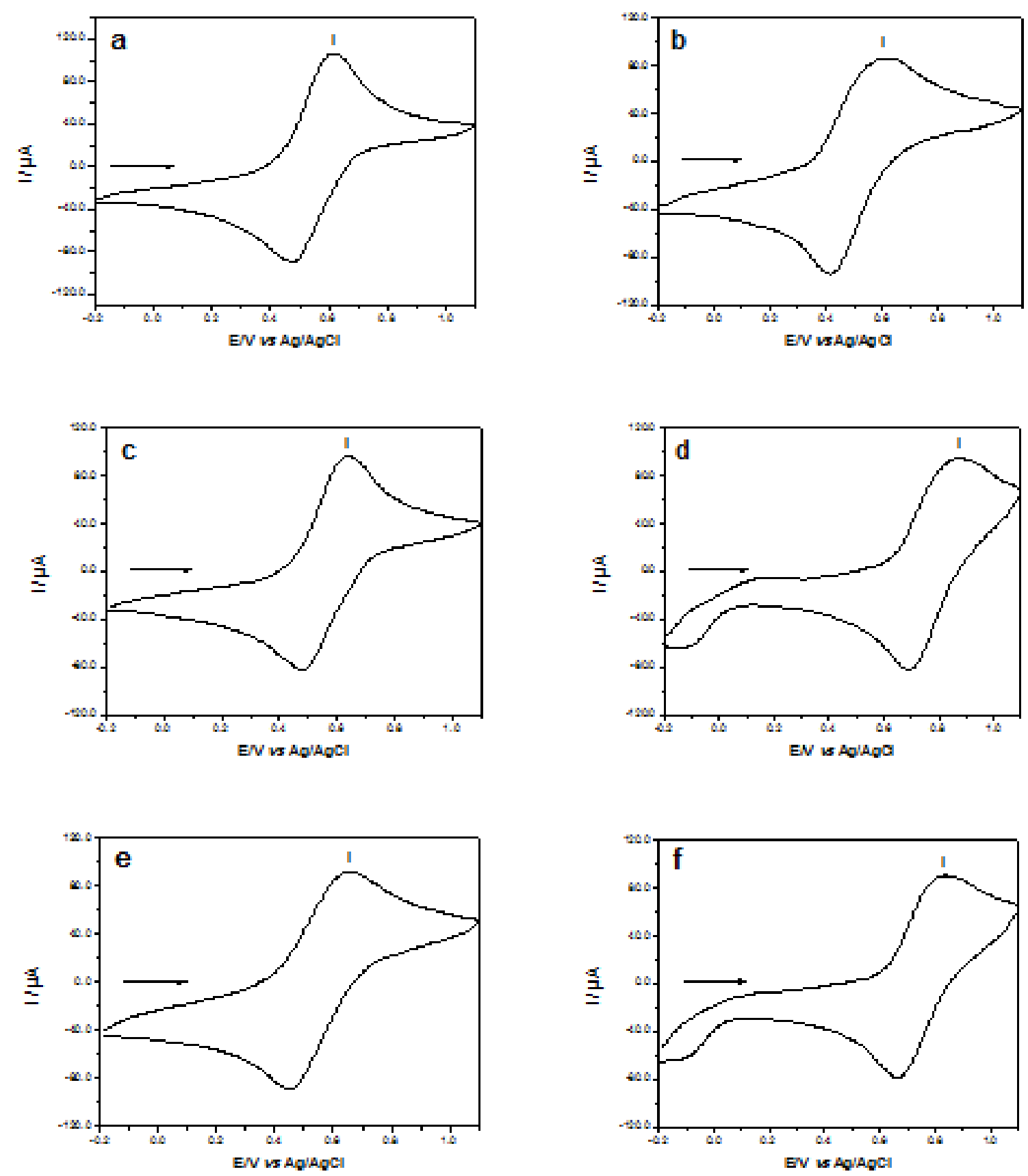

Figure 4. Influence of the nature of cations in the graphite electrode modified with TiPhNiHCF: (a) $\mathrm{KNO}_{3}$, (b) $\mathrm{NaNO}_{3}$, (c) $\mathrm{KCl}$, (d) $\mathrm{NaCl}$, (e) $\mathrm{LiCl}$ and (f) $\mathrm{NaClO}_{4}\left(1.0 \mathrm{~mol} \mathrm{~L}^{-1} ; v=20 \mathrm{mV} \mathrm{s}^{-1}, 40 \% \mathrm{w}\right.$ ) 


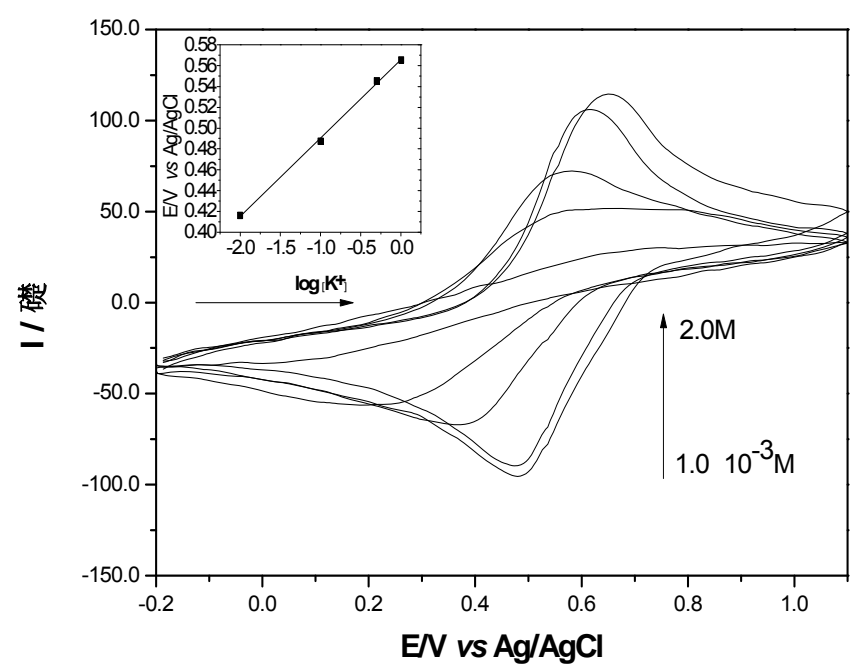

Figure 5. Cyclic voltammogram of graphite paste electrode modified with TiPhNiHCF in several concentrations $\left(1.0 \times 10^{-3}-2.0 \mathrm{~mol} \mathrm{~L}^{-1}\right)$. (Inserted graphic: Average potential $\left(E^{\theta^{\prime}}\right)$ of graphite paste modified with TiPhAgHCF as a function of $\log$ concentration of $\mathrm{KNO}_{3}$ )

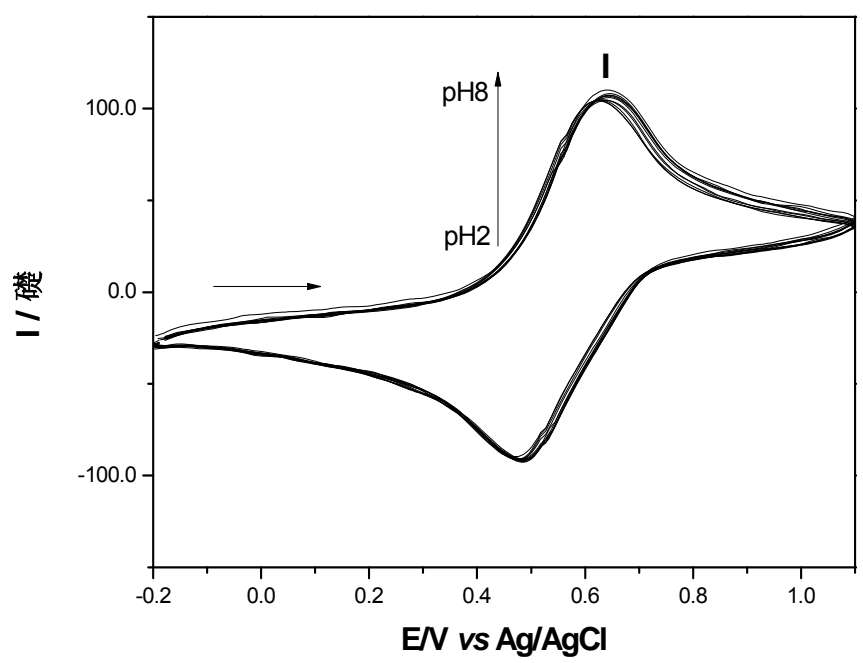

Figure 6. Cyclic voltammogram of graphite paste modified with TiPhNiHCF to different $\mathrm{pH}$ values (2 - 8); $\left(\mathrm{KNO}_{3} 1.0 \mathrm{~mol} \mathrm{~L}^{-1}, v=20 \mathrm{mV} \mathrm{s}^{-1}\right)$

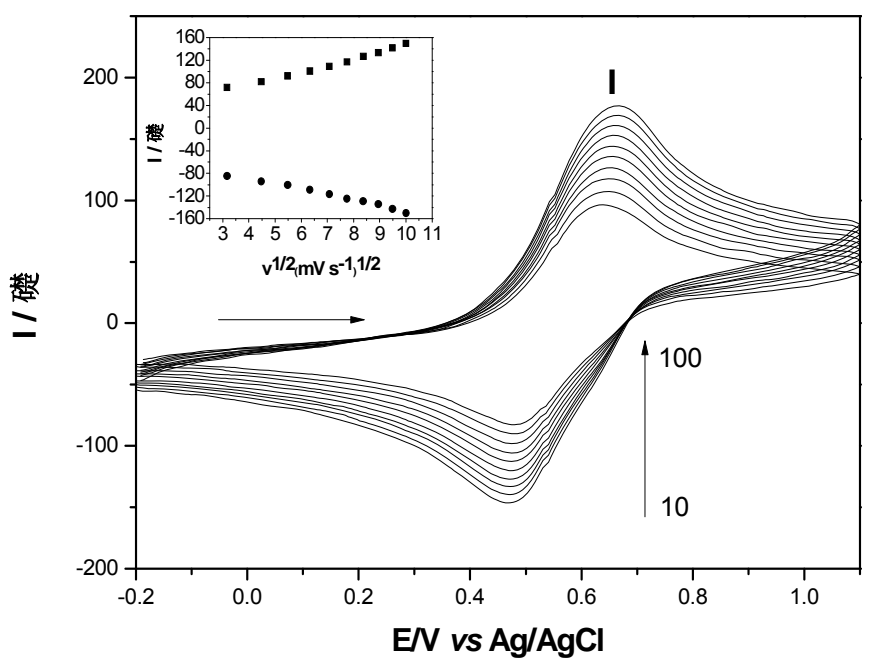

Figure 7. Cyclic voltammogram of TiPhNiHCF at different scan rates: $10-100 \mathrm{mV} \mathrm{s}^{-1} ;\left(\mathrm{KNO}_{3} 1.0 \mathrm{~mol} \mathrm{~L}^{-1} ; \mathrm{pH}\right.$ 7.0). (Inserted graphic: Dependence of current peak $I$ (anode and cathode) with the square root of scan rate) 


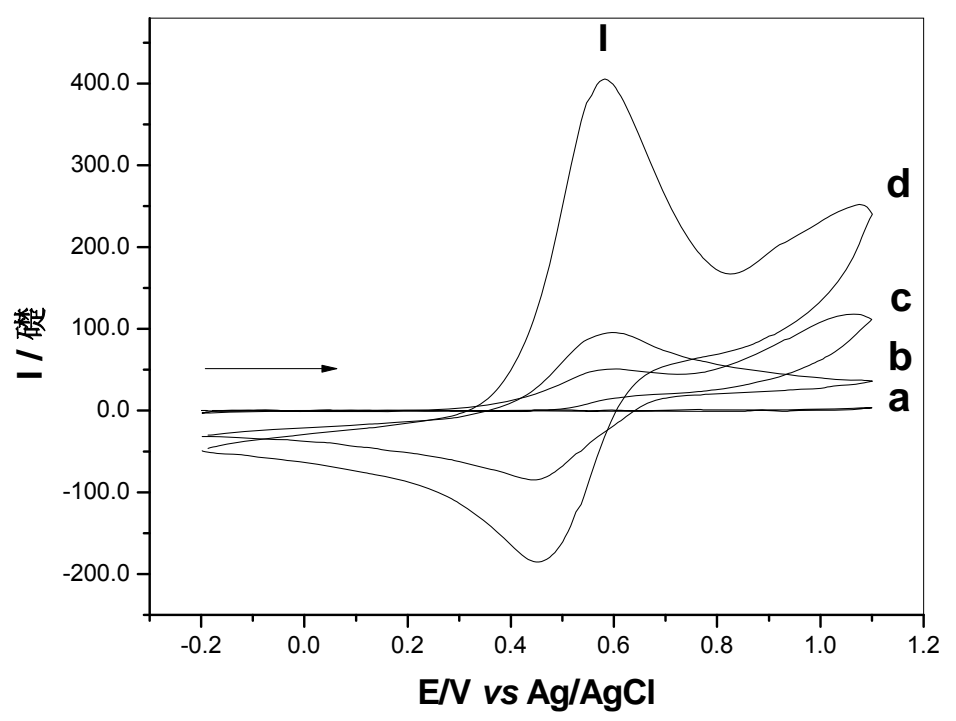

Figure 8. Cyclic voltammogram of: a) graphite paste electrode; c) graphite paste electrode in $1.0 \times 10^{-2} \mathrm{~mol} \mathrm{~L}^{-1}$ Dipyrone; b) graphite paste electrode modified with TiPhNiHCF; d) graphite paste electrode modified with TiPhNiHCF and $1.0 \times 10^{-2} \mathrm{~mol} \mathrm{~L}^{-1}$ Dipyrone $\left(\mathrm{KNO}_{3} 1.0 \mathrm{~mol} \mathrm{~L}^{-1} ; v=20 \mathrm{mV} \mathrm{s}^{-1}\right)$

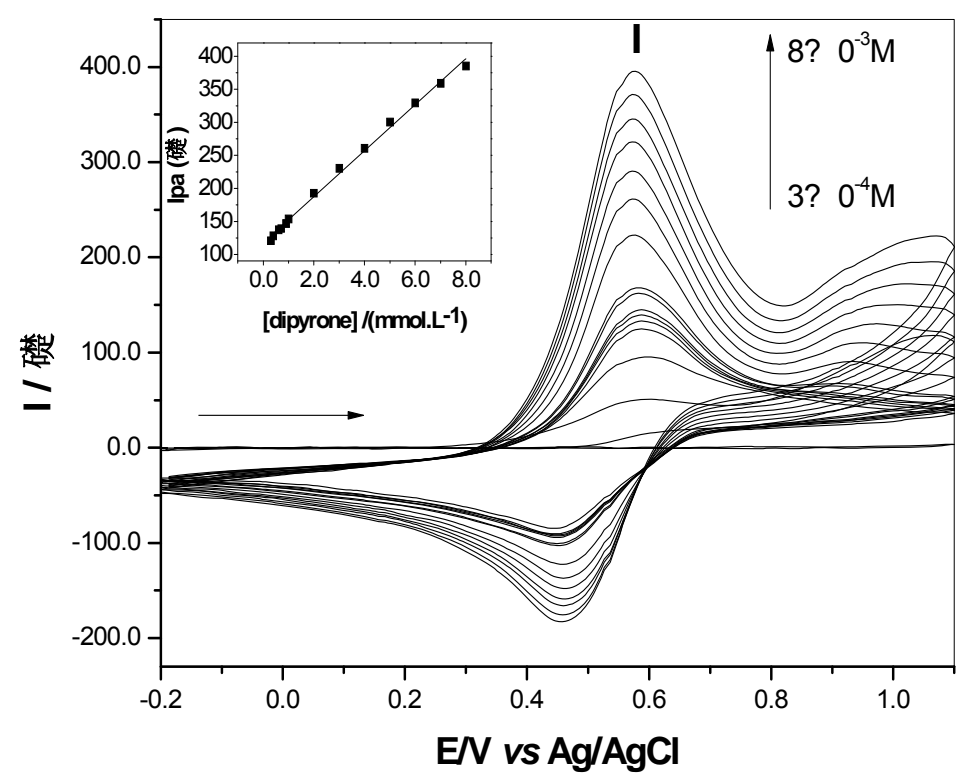

Figure 9. Cyclic voltammograms of the applications of various concentrations of Dipyrone using a graphite paste electrode modified with TiPhNiHCF $\left(\mathrm{KNO}_{3} 1.0 \mathrm{~mol} \mathrm{~L}^{-1} ; v=20 \mathrm{mV} \mathrm{s}^{-1}\right)$. (Inserted graphic: Analytical curve of the anodic peak for the determination of Dipyrone using a graphite paste electrode modified with TiPhNiHCF $\left(\mathrm{KNO}_{3} 1.0 \mathrm{~mol} \mathrm{~L}^{-1}, \mathrm{pH} 7.0 ; v=20 \mathrm{mV} \mathrm{s}^{-1}\right)$ 